\title{
Twelve-Year Mapping and Change Analysis of Eelgrass (Zostera marina) Areal Abundance in Massachusetts (USA) Identifies Statewide Declines
}

\author{
Charles T. Costello • William Judson Kenworthy
}

Received: 19 May 2009/Revised: 16 September 2010 /Accepted: 27 December 2010 / Published online: 20 January 2011

(C) Coastal and Estuarine Research Federation 2011

\begin{abstract}
In 1994, 1995, and 1996, seagrasses in 46 of the 89 coastal embayments and portions of seven open-water near-shore areas in Massachusetts were mapped with a combination of aerial photography, digital imagery, and ground truth verification. In the open-water areas, $9,477.31$ ha of seagrass were identified, slightly more than twice the $4,846.2$ ha detected in the 46 coastal embayments. A subset of the 46 embayments, including all regions of the state were remapped in 2000, 2001, and 2002 and again in 2006 and 2007. We detected a wide range of changes from increases as high as $29 \% \mathrm{y}^{-1}$ in Boston Harbor to declines as large as $-33 \% \mathrm{y}^{-1}$ in Salem Harbor. One embayment, Waquoit Bay, lost all of its seagrass during the mapping period. For the 12-year change analysis representing all geographic regions of the state, only three embayments exhibited increases in seagrass coverage while 30 of the original 46 embayments showed some indication of decline. For the decadal period, rates of decline in the individual embayments ranged from $-0.06 \% \mathrm{y}^{-1}$ to as high as $-14.81 \% \mathrm{y}^{-1}$. The median rate of decline by region ranged from $-2.21 \% \mathrm{y}^{-1}$ to $-3.51 \% \mathrm{y}^{-1}$ and was slightly less than the recently reported global rate of decline for seagrasses $\left(-3.7 \% \mathrm{y}^{-1}\right)$. Accounting for the
\end{abstract}

Electronic supplementary material The online version of this article (doi:10.1007/s12237-010-9371-5) contains supplementary material, which is available to authorized users.

C. T. Costello $(\bowtie)$

Division of Watershed Management, Massachusetts Department of Environmental Protection,

1 Winter Street,

Boston, MA 02108, USA

e-mail: charles.costello@state.ma.us

W. J. Kenworthy

Center for Coastal Fisheries and Habitat Research,

NCCOS, NOS, NOAA,

101 Pivers Island Rd.,

Beaufort, NC 28516, USA gains in three of the embayments, 755.16 ha $(20.6 \%)$ of seagrass area originally detected was lost during the mapping interval. The results affirm that previously reported losses in a few embayments were symptomatic of more widespread seagrass declines in Massachusetts. State and Federal programs designed to improve environmental quality for conservation and restoration of seagrasses in Massachusetts should continue to be a priority for coastal managers.

Keywords Massachusetts · Seagrass · Distribution · Mapping · Change analysis · Declines · Water quality

\section{Introduction}

The ecological and economic importance of the seagrass Zostera marina (eelgrass) in coastal waters of the western Atlantic are widely known (Thayer et al. 1984; Moore and Short 2006; Orth et al. 2006c). As far back as the sixteenth and seventeenth centuries, Z. marina was recognized for its value in sustaining waterfowl, providing habitat for fisheries, substrate for shellfish, and as a crucial component of sediment and shoreline stabilization (Lewis and Cottam 1936; Cottam and Munro 1954). Humans harvested eelgrass for use as insulation, filler materials in bedding, and as compost for agriculture (Cottam 1934; Cottam and Munro 1954; Wyllie-Echeverria et al. 2000). Concern for the loss of these valuable services was magnified in the 1930s when the "wasting disease" decimated a large fraction of the North Atlantic populations of Z. marina, including populations in Massachusetts (Rasmussen 1977; Short et al. 1988). This large-scale decline led to a coast-wide reconnaissance of eelgrass abundance and numerous local investigations that continued for nearly three decades (Cottam 1933; Addy and Aylward 1944; Dexter 1953; Cottam and Munro 1954). However, it was not until the 1980s when the first attempts were made to quantitatively map seagrass 
distribution and abundance in selected portions of the Massachusetts coast on a large scale (Costa 1988).

Costa (1988) identified 4,099 ha of Z. marina along a portion of the Massachusetts coastline in the near-shore waters of Buzzards Bay and predicted that eelgrass was returning to its former abundance prior to the wasting disease. Costa also identified embayments where $Z$. marina had not yet returned in water bodies corresponding with nitrogen loading, degraded water quality, and eutrophication (Valiela and Costa 1988; Costa et al. 1992). In Waquoit Bay on the south shore of Cape Cod (Fig. 1), seagrass declines were directly linked to eutrophication caused by nitrogen loading from septic tanks (Valiela et al. 1992; Short and Burdick 1996). Subsequent empirical and modeling studies in Massachusetts estuaries have linked land-derived nitrogen loading through groundwater and other sources directly to the growth of macroalgae and the decline of Z. marina (Hauxwell et al. 2001, 2003; McGlathery 2001; Fox et al. 2008). Eutrophication causes excessive organic enrichment in sediments, acute and chronic anoxia, and severe physiological stress on eelgrass plants that may already be experiencing light limitation (Holmer and Laursen 2002). Unlike situations where degraded optical water quality reduces light penetration and threatens plants mostly in the deeper water, the effects of multiple stressors associated with eutrophication cause more widespread losses of eelgrass which are not just confined to the deepest edges of the seagrass beds.

Results from the studies in Massachusetts and several related national and international research programs have converged to identify the detrimental effects of nutrient enrichment and eutrophication in coastal waters including large-scale declines of seagrass meadows (Krause-Jensen et al. 2008; Orth et al. 2006c; Waycott et al. 2009). These studies suggested that seagrass can potentially serve as sentinels of coastal environmental change associated with natural and anthropogenic disturbances (Cambridge and McComb 1984; Dennison et al. 1993; Biber et al. 2004). With appropriate temporal and spatial scaling, monitoring environmental quality and mapping the changes in seagrass distribution and abundance can provide scientists and managers with a sensitive tool for detecting and diagnosing environmental conditions responsible for the loss or gain of seagrasses. Such a tool can help to establish realistic goals in estuarine ecosystem restoration programs (Tomasko et al. 2001; Kemp et al. 2004; Steward and Green 2007; Waycott et al. 2009; Orth et al. 2010). Based on this, the Massachusetts Department of Environmental Protection (MADEP) initiated a statewide "eelgrass change analysis program" (sensu Dobson et al. 1995; Finkbeiner et al. 2001) to determine if $Z$. marina declines reported in portions of Buzzards and Waquoit Bays were more widespread in Massachusetts. The specific objectives of this paper are to present the results of the statewide baseline resource inventory of the distribution and abundance of eelgrass in 46 coastal embayments and seven open-water areas beginning in 1994, and to conduct a change analysis of eelgrass abundance between 1994 and 2007 in 33 coastal embayments throughout all regions of the state. The implications of the results are discussed in the context of (1) the ongoing seagrass declines in Massachusetts and declines worldwide, (2) the identification of priority watersheds targeted for development of water quality remediation plans, and (3) the formulation of a conservation and restoration plan for eelgrass based on trends indicated by the change analysis.

\section{Methods}

\section{Study Site}

Massachusetts (MA) has approximately 2,400 km of shoreline extending along the mainland coast of southeastern New England, USA (Fig. 1). The geology and hydrology of the Massachusetts coastline is a remnant feature of the Wisconsin stage of the last glacial period when a massive ice sheet covered portions of the North American continent extending as far south as Cape Cod (Odale 1992). The melting glaciers carved out numerous shallow estuaries, brackish water coastal ponds, outwash plains, and formed a series of offshore island features and coastal shelves. The Elizabeth Island chain forms the southeastern boundary of Buzzards Bay while Martha's Vineyard and Nantucket partially enclose the waters of Nantucket and Vineyard Sounds. The unconsolidated substrates in the coastal embayments are made up of mud, silt, sand, and coarse-grained siliceous sediments in water depths now generally $<3-5 \mathrm{~m}$ deep. Mixed in with these are larger rubble, boulders, shell material, and ledges, forming a complex submerged geology. Outside the embayments, adjacent to the south coast, there are extensive submerged open-water features including a series of broad, semiprotected shelves in Buzzards Bay, Vineyard Sound, and Nantucket Sound. These shelves are relatively deeper than the coastal embayments $(>3-10 \mathrm{~m})$ and partially shielded from the open Atlantic by the islands and peninsulas. These open coastal waters are exposed to higher tidal and wave energy and communicate with the embayments through tidal inlets. North of the Cape Cod peninsula are two large bodies of water, Cape Cod Bay and Massachusetts Bay, which extend up to the Gulf of Maine. Cape Cod Bay has a broad, relatively shallow shelf with unconsolidated sandy sediments extending several kilometers offshore and partially protected from the open Atlantic by Cape Cod. With few rivers supplying fresh water and a generally temperate climate, the physical, chemical, and geological conditions 


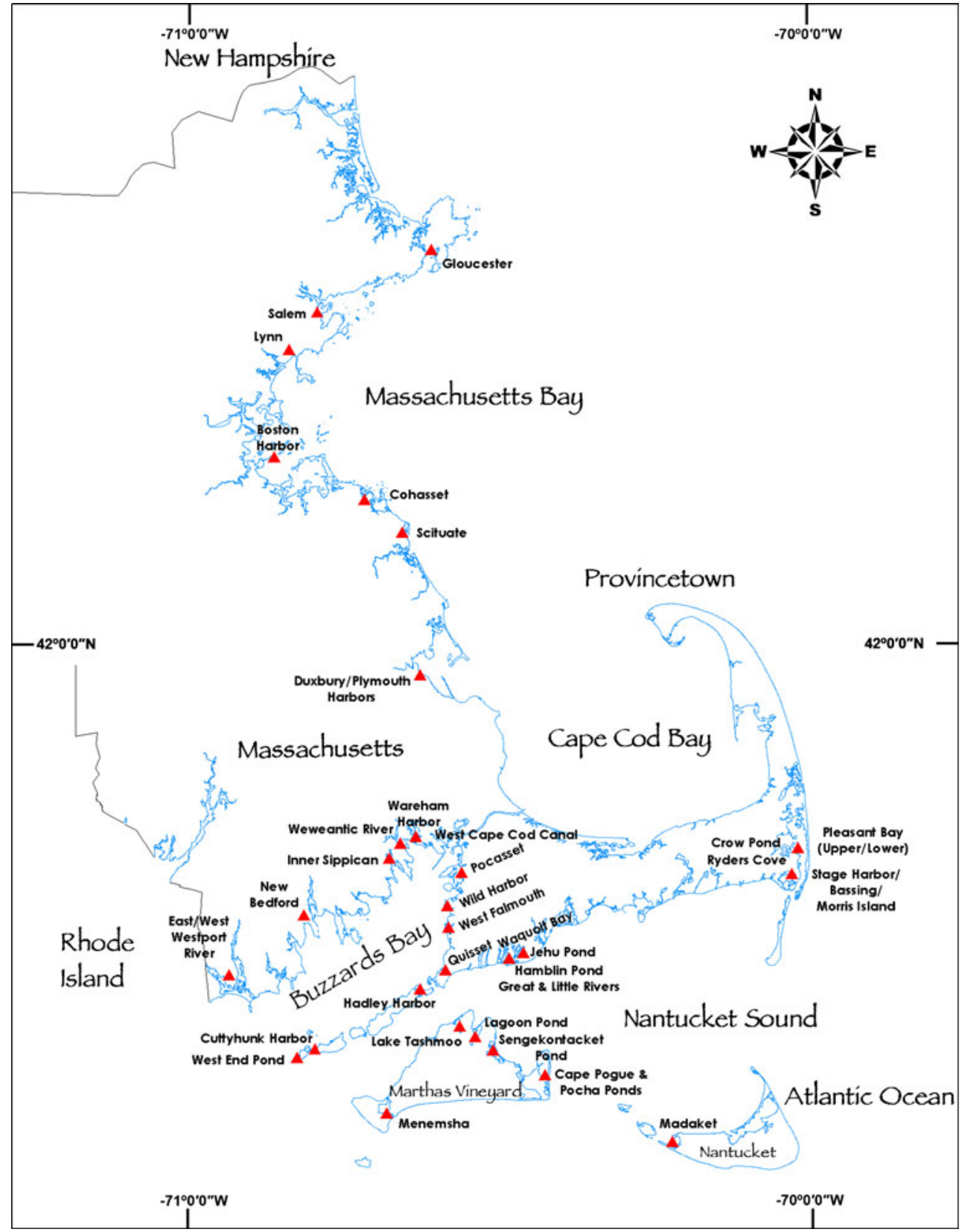

Fig. 1 Illustration of the Massachusetts shoreline features showing 33 embayments (black triangles), and open-water areas of Massachusetts Bay, Cape Cod Bay, Nantucket Sound, and Buzzards Bay

throughout Massachusetts coastal waters are ideally suited for the growth of two species of seagrass, Z. marina (eelgrass) and Ruppia maritima (wigeongrass).

\section{Statewide Seagrass Mapping 1994-2007}

The Massachusetts statewide seagrass mapping effort was conducted in three phases beginning in 1994 and ending in 2007. The initial mapping phase $\left(t_{1}\right)$ was carried out in 1994, 1995, and 1996. Aerial photography obtained for 46 embayments distributed throughout the four regions, eight in the north shore, 17 in the south shore of Cape Cod, 14 in Buzzards Bay, and seven in the Islands (Fig. 1). We also acquired aerial photography for the open-water areas of Massachusetts Bay, Cape Cod Bay, Nantucket/Vineyard Sounds, and Buzzards Bay (Fig. 1). Photography for the Island embayments and the adjacent open-water areas was obtained in 1994 for the embayments from Scituate to Provincetown, and open-waters of Cape Cod Bay and the south shore of Cape Cod in 1995, and for the embayments from Boston Harbor to the New Hampshire state line and in Buzzards Bay, including their open-waters, in 1996. 
In the second phase $\left(t_{2}\right), 29$ of the original 46 embayments were remapped in 2000, 2001, and 2002 with aerial photography of the embayments of Martha's Vineyard and embayments from Cohasset to Provincetown (2000), the embayments from Boston Harbor to the New Hampshire state line, and the south shore of Cape Cod and Nantucket Island (2001), and with digital imagery of the embayments in Buzzards Bay (2002).

The third phase $\left(t_{3}\right)$ was carried out in 2006 and 2007 using digital imagery and focused on remapping of 33 of the original 46 embayments including 29 mapped in $t_{2}$ with representative embayments in all four regions including seven in the north shore, seven in the south shore of Cape Cod, 13 in Buzzards Bay, and six on the Islands.

\section{Data Acquisition and Image Interpretation}

\section{Aerial Photography}

Analog aerial photography was obtained according to the general protocols developed by NOAA's Coastal Change Analysis Program (C-CAP; Dobson et al. 1995; Finkbeiner et al. 2001; www.csc.noaa.gov/ccap). Specifically, we utilized true color aerial photography (Kodak Aerochrome 2448) taken at a scale of 1:20,000. The photography was captured during the active $Z$. marina growing season in Massachusetts between May and early August when aboveground biomass was highest and the benthic signature is strongest. Specifications required acquisition of the photography when conditions were as near to low tide as possible, sun angle $<25^{\circ}$, winds were $<5 \mathrm{mph}$, cloud cover was minimal, and there was no haze, no fog, and no rainfall or high wind conditions within previous $48 \mathrm{~h}$.

Prior to interpretation, sample images were checked for quality within $48 \mathrm{~h}$ of acquisition. Segments of flight lines that were rejected were reflown in the next available window of acceptable environmental conditions within the same growing season. For interpretation, 9" $\times 9^{\prime \prime}$ colornegative transparencies were examined and polygons of seagrasses were delineated and drafted on acetate transparent film using a binocular stereoscope (Cartographic Engineering Modular Stereoscope Model SB 190).

The aerial photos, with the interpreted acetates attached, were scanned using a photogrammetric quality scanner (AGFA Horizon Plus) at a resolution of 600 dpi resulting in a pixel resolution of $0.85 \mathrm{~m}$. The resulting image file was rectified (bilinear second order) by C-CAP to $1 \mathrm{~m}$ black and white and color digital orthophotos supplied by Massachusetts Coastal Zone Management. The seagrass polygon delineations from the rectified image were then digitized on screen. In addition, a point file was generated based on field-verified sites as well as all occurrences of widgeon grass $R$. maritima (widgeon grass) and macroalgae. The rectification and digitization was completed utilizing the ERDAS Imagine software. For aerial photography acquired in 2000 and 2001, the color images were scanned at a resolution of $260 \mathrm{dpi}$ and geo-referenced using ESRI ArcView Image Analyst software to the $0.5 \mathrm{~m}$ MA digital orthophoto quad map series used as the MA statewide-base map resulting in a collection of files (.img) having an average RMS of 1.91. Seagrass coverage was interpreted on screen from the digitized images.

\section{Digital Imagery}

Digital imagery was acquired in 2002, 2006, and 2007 through a contract with GeoVantage Corporation (Peabody, MA, USA). The GeoVantage sensor consists of a digital camera with four bands centered on blue $(450 \mathrm{~nm})$, green $(550 \mathrm{~nm})$, red $(650 \mathrm{~nm})$, and near-infrared $(850 \mathrm{~nm})$. The output of the camera system are GeoTiff image products which were created from the true color imagery captured with a $0.5 \mathrm{~m}$ ground sample distance resolution and 8-bit radiometric resolution. The images were orthorectified, terrain-corrected (using 7.5 m USGS DEMs), georegistered, and mosaics were created for each flight mission with a spatial accuracy of $\pm 3 \mathrm{~m}$ ( $90 \%$ of pixels). The digital images were interpreted monoscopically on screen.

The digital imagery was analyzed and interpreted using a high resolution CRT 22-in. monitor. Polygons of seagrass were hand-digitized on screen using the ArcGIS 9 suite of software.

\section{Change Analysis}

We conducted three separate change analyses in embayments representing all four regions of the state. In the first change analysis, we evaluated the change in seagrass areal abundance (ha) between the first mapping in 1994, 1995, and 1996 (referred to as $t_{1}$ ) and the second mapping in 2000, 2001, and 2002 (referred to as $t_{2}$ ). In this change analysis, we remapped 29 of the original 46 embayments. For the second change analysis in 2005, 2006, and 2007 (referred to as $t_{3}$ ), we remapped 29 of the original 46 embayments and conducted a change analysis between $t_{2}$ and $t_{3}$. In the third change analysis, we also evaluated the change in seagrass areal abundance over the entire mapping interval (1994-2007) for 33 of the original 46 embayments that were mapped in the initial $\left(t_{1}\right)$ and final $\left(t_{3}\right)$ mapping. Percentage rates of change $\left(\mu, \% \mathrm{y}^{-1}\right)$ for each site were calculated over time interval $(\mathrm{t})$ from the initial to final areas $\left(A_{o}\right.$ and $A_{t}$, respectively) as, $\mu=\left[\ln \left(A_{t} / A_{o}\right) / t\right] \times 100$ (Waycott et al. 2009). Median rates of change in each region during each of the three mapping periods were calculated as was a decadal time scale analysis for all the mapped embayments. 


\section{Accuracy and Error Assessment}

Much of the MA coast has a sandy substrate providing a useful color contrast to map the darker seagrass photo signatures. None-the-less, there are still uncertainties with signature interpretation that required field verification. Extensive fieldwork was conducted to develop a quantitative understanding of the signatures and gather surface level data where the presence or extent of habitat was not apparent from the photography. In the initial and final mapping effort, we conducted accuracy assessments with nearly equal distribution of points from each region mapped. In areas where the initial interpretation of the imagery was questioned, field survey work was conducted to determine the outer edges of seagrass polygons utilizing underwater video camera transects. These transects were conducted by towing the underwater video camera through the eelgrass bed into the deeper water beyond where the outer or deeper edge of eelgrass was located. Using a differential global positioning system (DGPS), data points of the outer edges were entered into the GIS database. Specific areas where fieldwork information and underwater videography were obtained were marked on the acetate overlays and digital images to assist in signature and edge verification.

Seagrass polygon vector coverages were assessed for accuracy in July 1997, September 1998 (205 points), and again in September and October 2007 (260 points). The assessments were based on random points generated within the polygon boundaries by the Hawth's tools extension within the ArcMap GIS environment. Navigation to each point in the field was accomplished using DGPS ( $<1 \mathrm{~m}$ accuracy). The underwater video camera was used to verify the presence of the mapped feature at the random point.

\section{Results}

Baseline Mapping; 1994, 1995, and 1996

The baseline coverage of seagrass in the 46 embayments initially mapped in 1994, 1995, and 1996 was 4,846.32 ha (Table 1). The 46 locations represent approximately half of the 89 estuarine embayments identified in the MADEP Estuaries Program and cover all coastal regions of the state, including the outer islands (http:/www.mass.gov/dep/water/ resources/mepproj.htm, http://www.oceanscience.net/estuar ies/index.htm). The seagrasses in the 46 embayments were composed almost exclusively of monotypic $Z$. marina beds and a very small amount of $R$. maritima observed in just six locations. The largest $R$. maritima coverage (1.72 ha) was confirmed in Great River on the south shore of Cape Cod in 2006. In most of the protected embayments, the $Z$. marina beds consisted of mixtures of nearly continuous meadows
Table 1 Data for hectares of seagrass mapped in 46 embayments and seven Massachusetts open-water areas in 1994, 1995, and 1996

\begin{tabular}{lc}
\hline Location & Hectares \\
\hline Embayments $(n=46)$ & $4,846.32$ \\
Nantucket Sound open-water & $4,201.56$ \\
Cape Cod Bay open-water & $3,149.56$ \\
Martha's Vineyard open-water & $1,140.96$ \\
Elizabeth Islands open-water & 485.592 \\
North Shore open-water & 262.83 \\
Buzzards Bay open-water & 184.36 \\
South Shore open-water & 52.43 \\
Total & $14,323.63$ \\
\hline
\end{tabular}

with well-delineated boundaries as well as varying sized patches of grass that marked the upper distribution in the lower intertidal zone and the deeper light limited edges coinciding with the lower depth distribution.

The seven open-water areas had an estimated total of $9,477.31$ ha of seagrass, approximately twice the acreage of the 46 embayments (Table 1). The largest acreage in openwater occurred in Nantucket Sound followed by Cape Cod Bay. Combined, these two had as much seagrass coverage as all of the 46 embayments (Table 1). Many of the openwater seagrass beds in Massachusetts cover large areas of coastline but occur in very patchy distributions with mosaics of small $\left(<1-5 \mathrm{~m}^{2}\right)$ and large $\left(>5-10 \mathrm{~m}^{2}\right)$ patches of eelgrass characteristic of the typical open-water seagrass landscapes found along shorelines exposed to high currents and waves (Fonseca and Bell 1998; Bell et al. 2006).

The interpreted signatures for the open-water areas underestimate the total amount of seagrass for this type of habitat. This results from the limited ability of the imagery to penetrate to the maximum depth at which seagrasses grow in the more opaque deeper water regions $(>5 \mathrm{~m})$. Change analyses in the open-water areas are not possible by remote sensing (aerial or satellite imagery) alone and requires additional underwater technologies (divers, ROVs, etc.) to fully assess the abundance of these seagrass beds.

Accuracy assessments conducted in the first mapping effort $\left(t_{1}\right)$ in the 46 embayments indicated that we were able to correctly identify seagrass $>85 \%$ of the time and improved to $94 \%$ in third mapping effort $\left(t_{3}\right)$. Errors in misclassification of algal signatures as seagrass was the most common error and may be responsible for a slight overestimation of seagrass cover in the embayments.

\section{Change Analyses}

For the first change analysis $\left(t_{1}-t_{2}\right)$, only one embayment, Cohasset Harbor, exhibited an increase in seagrass 
abundance $\left(0.75 \% \mathrm{y}^{-1}\right)$, while the remaining 28 either declined or showed little change (e.g., New Bedford Harbor; Table 2). Several of the embayments experiencing declines lost their entire eelgrass coverage during the period from the initial mapping to the second mapping (data not shown in Table 2). The embayments which lost all of their eelgrass included Buttermilk Bay in northeastern Buzzards Bay (43.1 ha), and Great and Perch Pond systems (8.95 ha), Eel Pond (0.74 ha), and Three Bays (5.09 ha).

By region, median rates of loss in the declining embayments during the first change analysis $\left(t_{1}-t_{2}\right)$ were highest along the south shore of Cape Cod $\left(-7.73 \% \mathrm{y}^{-1}\right)$ and were influenced by the high rates of loss in Hamblin, Waquoit, Upper Pleasant Bay, and the Stage Harbor System (Table 2). For the other three regions, median rates of loss in the declining embayments were similar, ranging from $-3.52 \%$ $\mathrm{y}^{-1}$ on the Islands to $-4.5 \% \mathrm{y}^{-1}$ in Buzzards Bay and -3.5 $9 \% \mathrm{y}^{-1}$ on the north shore. Notable were the high rates of loss in the north shore observed in Salem $\left(-33.86 \% \mathrm{y}^{-1}\right)$ and Boston Harbors $\left(-22.11 \% \mathrm{y}^{-1}\right.$; Table 2). In Buzzards Bay, the highest rate of loss was observed at Wareham $\left(-24.76 \% \mathrm{y}^{-1}\right)$ and Weweantic River $\left(-14.13 \% \mathrm{y}^{-1}\right)$. On the Islands, the highest rates of loss were observed in Lagoon Pond $\left(-13.62 \% \mathrm{y}^{-1}\right)$ and Lake Tashmoo $\left(-14.47 \% \mathrm{y}^{-1}\right)$.

In the second change analysis $\left(t_{2}-t_{3}\right), 11$ of the 29 embayments displayed some degree of increase in area while 19 showed declines (Table 2). Increases were present in each region with three of the largest increases recorded in the north shore at Boston $\left(29.22 \% \mathrm{y}^{-1}\right)$, Salem $\left(9.73 \% \mathrm{y}^{-1}\right)$, and Gloucester Harbors $\left(9.46 \% \mathrm{y}^{-1}\right)$. These three increases were a substantial reversal of the declines each location experienced in the first change analysis, and surpassed the rates of increase recorded in the other eight improving embayments. During the second change analysis, the median rate for all of the increasing sites was $2.44 \% \mathrm{y}^{-1}$.

With the notable exception of Waquoit Bay $\left(-20.00 \% \mathrm{y}^{-1}\right)$, which lost all of its eelgrass during the second mapping interval $\left(t_{2}-t_{3}\right)$, rates of loss in the declining embayments were not nearly as pronounced in the second change analysis. By region, the median rates of loss for declining embayments was $-0.50 \% \mathrm{y}^{-1}$ on the North Shore, $-1.21 \%$ $\mathrm{y}^{-1}$ on the south shore of Cape Cod, $-3.49 \% \mathrm{y}^{-1}$ in Buzzards Bay, and $-2.52 \% \mathrm{y}^{-1}$ on the Islands.

For the 33 embayments we mapped over the entire mapping interval $\left(t_{1}-t_{3}\right), 30$ showed declines (Table 2). Only Gloucester $\left(2.39 \% \mathrm{y}^{-1}\right)$, Cuttyhunk $\left(6.54 \% \mathrm{y}^{-1}\right)$, and New Bedford Harbors $\left(1.30 \% \mathrm{y}^{-1}\right)$ exhibited increases in coverage for the entire time period. By region, in the declining embayments, median rates of loss were similar with the highest rate in Buzzards Bay $\left(-3.51 \% \mathrm{y}^{-1}\right)$, followed by the south shore of Cape Cod $\left(-3.39 \% \mathrm{y}^{-1}\right)$, the North Shore $\left(-2.39 \% \mathrm{y}^{-1}\right)$, and the Islands $(-2.21 \%$ $\mathrm{y}^{-1}$ ). There were large differences between individual embayments within and among regions. Each region had embayments with loss rates representing both the fastest (Salem Harbor $=-10.9 \% \mathrm{y}^{-1}$, Hamblin $=-14.55 \% \mathrm{y}^{-1}$, Wareham Harbor $=-14.81 \% \mathrm{y}^{-1}$, Lagoon Pond $=-9.70 \%$ $\mathrm{y}^{-1}$ ) and the slowest rates (Cohasset $=-0.06 \% \mathrm{y}^{-1}$, Morris Island $=-0.84 \% \mathrm{y}^{-1}$, Hadley Harbor $=-0.37 \% \mathrm{y}^{-1}$, and Cape Pogue Pond $=-0.28 \% \mathrm{y}^{-1}$ ) observed statewide.

Considering all of the embayments that were assessed statewide that only showed declines, there appeared to be an improvement (less negative rates of decline) between the first and second change analyses (Fig. 2). During the initial mapping interval $\left(t_{1}-t_{2}\right)$, seagrass was declining at a median rate of $-4.50 \% \mathrm{y}^{-1}$, while in the second interval $\left(t_{2}-t_{3}\right)$ the decline rate was $-2.11 \% \mathrm{y}^{-1}$ (Fig. 2). For the entire mapping interval $\left(t_{1}-t_{3}\right)$, the median rate of decline was $2.94 \% \mathrm{y}^{-1}$ (Fig. 2). The box plot illustrates the distribution of the data in each mapping assessment with the presence of outliers (large negative rates) in each assessment period and for the entire mapping interval. The plots also show the distribution of the data. The first mapping period is much more skewed than the second period with a larger proportion of more negative values. For the entire mapping period, there is still evidence of a higher proportion of more negative values, but not as pronounced as in the first mapping period taken alone. The 30 embayments showing declines lost 774 ha, or about $20.65 \%$ of their seagrass. Accounting for the three gains (19.34 ha), the net loss in the 33 embayments was 755.16 ha.

\section{Discussion}

This is the first attempt to conduct a quantitative mapping assessment and change analysis of seagrass distribution and abundance in coastal embayments representing all the geographic regions of Massachusetts. The sites we mapped assessed approximately $50 \%$ of the state's embayments and sampled the full range of conditions for seagrasses growing in Massachusetts, including the first estimate of the abundance of seagrass in the open coastal waters (Table 1). The time scale over which this study occurred (12 years), and the examination of three time intervals in the change analysis, allowed us to evaluate trends in abundance extending beyond just the short-term seasonal and inter-annual fluctuations typically observed in temperate seagrass ecosystems responding to temperature, storm cycles, bioturbation, and ice scour (Duarte et al. 2006). Evaluation of trends in abundance at the time scales conducted in this study (5-12 years) will enable scientists and resource managers to better evaluate the correspondence between changes in seagrass abundance and longer-term environmental and anthropogenic factors affecting seagrasses growing in Massachusetts. 
Table 2 Data for hectares (ha) of seagrass mapped and change analyses in 33 Massachusetts embayments by region. Seagrasses were mapped at three times where $t_{1}=1994,1995$, and 1996; $t_{2}=2000$, 2001, and 2002; and $t_{3}=2006$ and 2007. Percentage rates of change $\left(\mu, \% \mathrm{y}^{-1}\right)$ for each site were calculated over the time interval $(t)$ from the initial to final areas ( $A_{o}$ and $A_{t}$, respectively) as, $\mu=\left[\ln \left(A_{t} / A_{o}\right) / t\right] \times 100$. Boldfaced and underlined values for $\mu$ indicate positive rates of change. Region means are based only on sites with declines. $n d=$ No data
Location by region $\quad$ AREA mapped (ha)

North Shore
Gloucester Harbor
Salem Harbor
Lynn Harbor
Boston Harbor
Cohasset Harbor
Scituate Harbor
Duxbury/Plymouth Harbor
Region median decline

South Shore Cape Cod

Upper Pleasant Bay

Lower Pleasant Bay

Ryders Cove/Crow Pond/Bassing Harbor

Morris Island

Stage Harbor System

Hamblin/Jehu Ponds and Great and Little Rivers

Waquoit Bay

Region median decline

Buzzards Bay

Cuttyhunk Harbor

Hadley Harbor

Quissett

West Falmouth

Wild Harbo

Pocasset Harbor

West Cape Cod Canal

Wareham Harbor

Weweantic Harbor

Inner Sippican Harbor

New Bedford Outer Harbor

West End Pond

East/West Branch Westport River

Region median decline

The Islands

Lagoon Pond

Lake Tashmoo

Menemsha

Sengekontacket Pond/Trapps Pond/Majors Cove

Cape Pogue, Pocha and Caleb Ponds

Madaket Harbor

Region median decline

ha $t_{1} \quad$ ha $t_{2} \quad$ ha $t_{3}$

$\begin{array}{rlr}18.55 & 15.03 & 21.12 \\ 41.93 & 7.71 & 12.55 \\ 289.42 & 259.20 & 272.01 \\ 81.48 & 26.97 & 47.04 \\ 45.61 & 47.35 & 45.32 \\ 4.84 & 4.18 & 4.17 \\ 910.27 & 792.4 & 772.76\end{array}$

$-4.21$

$-33.86$

$-2.21$

$-22.11$

0.75

$-2.97$

$-2.77$

$-3.59$

$\begin{array}{rl}121.36 & 76.34 \\ 521.63 & 473.7 \\ 64.29 & 48.22 \\ 69.15 & 57.67 \\ 105.62 & 65.37 \\ 29.91 & 6.96 \\ 10.23 & 5.95\end{array}$

5.36

22.45

20.93

22.55

8.31

16.73

157.99

4.54

20.93

64.26

42.73

1.25

273.99

$$
\begin{aligned}
& \text { nd } \\
& \text { nd } \\
& 17.97 \\
& 20.27 \\
& 7.04 \\
& 14.69 \\
& 98.34 \\
& 1.03 \\
& 8.96 \\
& 40.50 \\
& 40.80 \\
& \text { nd }
\end{aligned}
$$

nd

17.97

20.27

7.04

14.69

98.34

1.03

8.96

40.50

40.80

188.47
$-7.73$
$-1.61$
$-4.79$
$-3.02$
$-8.00$
$-24.30$
$-9.04$

$-7.73$

12.55
21.40
14.72
20.48
5.46
12.47
94.00
0.89
7.44
32.57
49.32
0.54
207.70

66.60

36.89

173.20

2.83

221.29

272.48
73.65
435.10
50.23
63.04
63.10
6.04
0.00

29.41

15.49

150.38

nd

179.18

244.73
20.78

15.33

129.27

2.23

213.95

244.89
$-13.62$

$-14.47$

$-2.35$

nd

$-3.52$

$-1.79$

$-3.52$

\begin{tabular}{l}
$\frac{\mathbf{9 . 4 6}}{\mathbf{9 . 7 3}}$ \\
$\frac{\mathbf{0 . 9 7}}{\mathbf{2 9 . 2 2}}$ \\
\hline-0.88 \\
-0.04 \\
-0.50 \\
-0.50
\end{tabular}




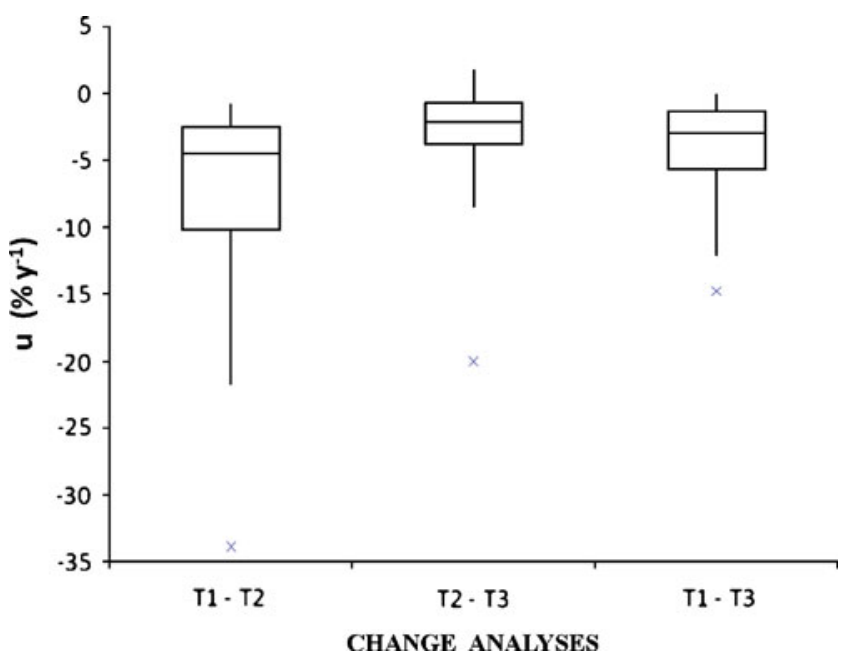

Fig. 2 Box and whisker plot showing the median rates of change ( $\mu=$ solid line inside each box) calculated for the embayments during each of three mapping intervals. $t_{1}-t_{2}$ Change analysis for the first mapping interval $(n=29) . t_{1}-t_{3}$ Change analysis for the second mapping interval $(n=29) . t_{1}-t_{3}$ Third change analyses covering the entire mapping interval $(n=33) . t_{1}=1995-1996-1997, t_{2}=2001-2002-2003, t_{3}=$ 2006-2007. Total number of embayments mapped in each change analysis $=n$. Boxes delineate the interquartiles, vertical whiskers show the data range, and outlier values are indicated as $x$

By far, the largest seagrass resources occurred on the open-water shelves where we mapped 9,477.31 ha during the initial assessment (Table 1, Supplementary Table 1). However, this is a substantial underestimate of their abundance in the oceanic waters because on the shelves seagrasses grow to depths that exceed the capability of the imagery sensors to detect their signatures in the deeper opaque waters. Unlike the situation in clear oligotrophic coastal systems where water transparency can be much better, in Massachusetts we do not have sufficient confidence in our ability to accurately detect seagrass and conduct a change analysis in the deeper water areas. To more completely assess the distribution and abundance of seagrasses in Massachusetts, it will be necessary to apply additional technologies such as SCUBA observations, underwater cameras, or acoustical devices. The openwater shelves are important resources providing a large amount of fish, shellfish, and wildlife habitat, as well as other important ecological services. One of the most important services they can provide is a source of new propagules from the production of flowers and seeds (Orth et al. 2006b). The large and widely distributed open-water meadows are likely to be one of the most important sources of potential new recruits for the coastal embayments, especially those which were impaired or remediated (Erftemeijer et al. 2008). To a certain extent, the openwater seagrass beds may appear less vulnerable to land derived stressors than the embayments; however, they are not isolated from the direct environmental effects of climate change (e.g., rising water temperature, shoreline destabilization, severe storms), or the potential anthropogenic impacts from channel and harbor maintenance, beach renourishment, and the development of alternative energy sources in the coastal zone (wind farms). State and federal resource agencies should continue efforts to map and monitor these valuable open-water coastal resources located outside of the embayments.

We are confident that we could accurately estimate the abundance of seagrasses in the shallow water embayments where we detected $4,846.32$ ha of seagrass. Based on our accuracy assessments, we may have overestimated this value by approximately $8-15 \%$. However, this value is still an underestimate of the total amount of this resource since we only mapped a little over $50 \%$ of the entire state's embayments during this study. Combining the statewide value for both the embayments and the open-waters, Massachusetts is steward to the one of the largest seagrass resources documented in the northwestern Atlantic and likely to be rivaled only by the seagrasses in Maine (Green and Short 2003).

Our change analysis data (Table 2 and Fig. 2) confirms that declines in seagrass are not just isolated cases in specific geographic locations. With the exception of just three sites displaying long-term increases (Gloucester, Cuttyhunk and New Bedford; Table 2), the results presented here corroborate earlier observations of seagrass declines in Buzzards Bay and Waquoit Bay (Costa 1988; Short and Burdick 1996) demonstrating these earlier reports were symptomatic of more widespread declines occurring in Massachusetts. During each mapping interval, the median rate of loss varied widely for the individual embayments and regions experiencing declines, but there was no evident pattern by region over the entire mapping period (Table 2). Median rates of decline were highest in the first mapping interval and improved in the second, subsequently the long-term rate (decadal scale) for the entire period would suggest a scenario of decline not nearly as severe as recorded during just the first interval (Fig. 2). The median rate of decline for the entire mapping interval (decadal scale) in Massachusetts $\left(-2.9 \% \mathrm{y}^{-} 1\right.$; Fig. 2) was slightly lower than the rate $\left(-3.7 \% \mathrm{y}^{-1}\right)$ reported in a recent global seagrass assessment (Waycott et al. 2009). The decadal time course analysis in the global study also showed that rates of decline were accelerating through this century, and in the two most recent decades they were $-5.0 \% \mathrm{y}^{-1}$ (Waycott et al. 2009). This would suggest that the apparent "within decade" improvement in the decline rate observed between the two mapping intervals in Massachusetts should be treated with caution. This, along with the total loss of seagrass in several embayments and the observed high rates in several other locations (Table 2), serves as a basis for concern regarding the overall status of seagrass populations in Massachusetts. 
Declines resulting in the complete loss of seagrass in several embayments during our study period are especially problematic for the semi-isolated embayments where natural recovery may be limited by the availability of propagules, either due to restricted circulation or the absence of nearby source populations (Orth et al. 2006b; Erftemeijer et al. 2008). Many of the embayments experiencing complete loss were located along the south coast of Massachusetts, on Cape Cod and Buzzards Bay, where evidence of seagrass declines were estimated to be as much as $65 \%$ in the past three decades (Valiela and Costa 1988; Short and Burdick 1996; Moore and Short 2006). The south coast of Massachusetts, especially the watersheds, communities, and shorelines on Cape Cod and Buzzards Bay, have experienced rapid population growth and development which is providing excessive sources of nutrients and land-derived runoff exceeding the capacity of the embayments to sustain eelgrass and resulting in significant eutrophication. Our more recent and wider scale assessment suggests that the mechanisms responsible for declines continue to have effects which are not yet sufficiently mitigated to reverse the previously reported trends from a few embayments, for example Buttermilk and Waquoit Bays which have lost all of their eelgrass, and Wareham Harbor which is declining at a rate of $14.8 \% \mathrm{y}^{-1}$. With a documented $20 \%$ loss statewide, the impact of these widespread losses may exacerbate the process of decline as fewer and fewer meadows are available to provide new recruits to sustain the seagrass populations. Furthermore, seagrasses are ecological engineers and their declines result in cumulative negative impacts that lead to the loss of important ecological services and regime shifts (Hauxwell et al. 2001; McGlathery 2001; Carpenter 2003; Scheffer and Carpenter 2003; Krause-Jensen et al. 2008; Duarte et al. 2007). Ecosystem state changes are evident in the most severely stressed embayments where seagrasses are declining and macroalgae have substituted for seagrass (Hauxwell et al. 2001).

Despite the overwhelming evidence for eelgrass declines throughout Massachusetts, many of the embayments have only small losses (Table 2). Improvements were evident in the second mapping interval where several locations exhibited increases in seagrass abundance. This may be a sign of improving conditions for seagrasses in some locations where management actions have been taken to enhance environmental quality. For example, the wastewater treatment plant in Boston Harbor was upgraded to secondary treatment and the outfall relocated $15 \mathrm{~km}$ further offshore to divert nutrient inputs away from the inner bay and to improve conditions for the seagrasses (Leschen et al. 2010). Our second change analysis indicates that seagrass may have responded positively to this management action. Seagrass coverage increased at a rate of $29.2 \% \mathrm{y}^{-1}$, mitigating a large loss during the first change analysis $\left(-22.1 \% \mathrm{y}^{-1}\right.$; Table 2). In Gloucester Harbor, a similar project to relocate the outfall was completed in 2000 and may be partly responsible for the improvements seen in the second change analysis where seagrasses increased at a rate of $9.4 \% \mathrm{y}^{-1}$ (Table 2). This positive response is not unprecedented. Given the appropriate conditions, eelgrass has the capability to recover from significant disturbance. Take, for example, the large scale reestablishment of $Z$. marina after its demise in the last glacial epic (Olsen et al. 2004) and the recovery of many populations across most of the north Atlantic after the wasting disease (Rasmussen 1977; Frederiksen et al. 2004). At a spatial scale comparable to the embayments in Massachusetts, Z. marina expanded into 5,000 ha of the northern coastal bays of Maryland in less than two decades (Orth et al. 2006a). Similar to the scale of Boston and Gloucester Harbors, a decadal scale recovery of Z. marina was recently documented in a small embayment on Long Island Sound following the removal of a municipal wastewater discharge source (Vaudrey et al. 2010). These observations, along with the observed rates of increase we have documented in the some of the managed embayments in Massachusetts (e.g., Boston Harbor, Table 2) are promising signs that environmental conditions exist in Massachusetts where seagrasses can either thrive or expand their populations if water quality is managed properly. Presently, the Massachusetts Department of Environmental Protection is collaborating with local municipalities to develop criteria for total maximum daily loads of nitrogen (TMDL) to protect seagrasses in coastal waters. Municipalities are being asked to spend millions of dollars to remediate their wastewater and non-point storm water discharges in order to improve water quality conditions. Documenting the long-term response of the seagrasses by continuing to map their distribution and abundance will be an essential component for determining the success of these management efforts as well as prioritizing where management actions are needed immediately in order to stabilize or reverse the declines.

\section{Conclusions and Recommendations}

The results of this study affirm that changes are occurring in the abundance of eelgrass in the coastal embayments of Massachusetts at rates similar to the reported global rates of change for seagrasses. Declines are widespread among all the coastal regions of the state including the complete loss of seagrasses in several embayments. Both natural and anthropogenic induced seagrass declines of the magnitude observed in several Massachusetts embayments are not unprecedented and serve as evidence of what can be expected if stressors are not identified and mitigated (Orth and Moore 1983; De Jonge and De Jong 1992; Short and Wyllie Echeverria 1996; Short 
and Burdick 1996; Fourqurean and Roblee 1999; Walker et al. 2006; Orth et al. 2010; Waycott et al. 2009). The rates over the past decade and the amount of lost acreage $(20 \%)$ suggest a time scale of 50 years for scientists and mangers to respond to a potentially significant loss throughout the coastal embayments of Massachusetts. There is also evidence of some stability and substantial improvements in a few locations which may be a result of improved water quality management. The rates of change we report here provide scientists an opportunity to identify and evaluate potential "cause and effect" relationships between eelgrass change (loss/gain) and environmental quality. Our results also provide a quantitative basis for managers to identify and prioritize locations needing the most immediate remediation and the incentives to begin developing a time frame for the actions necessary to avoid a larger and longer-term catastrophe. Given the high proportion of embayments exhibiting declines $(\approx 90 \%)$, mapping and change analyses should be coupled with studies of environmental quality (e.g., optical water quality, increasing water temperatures) to gain a more comprehensive understanding of the causes and severity of conditions affecting seagrasses in the embayments and open-water meadows.

Acknowledgments This research was funded by the Commonwealth of Massachusetts Department of Environmental Protection. We thank Kathy Cronin, Jim Brown, Michael McHugh, Don Field, and Brooke Landry for laboratory and field assistance. Salary and equipment funding for W. Judson Kenworthy were provided by the Center for Coastal Fisheries and Habitat Research, NCCOS, NOS, NOAA.

\section{References}

Addy, C.E., and D.A. Aylward. 1944. Status of eelgrass in Massachusetts during 1943. Journal of Wildlife Management 8: 269-275.

Bell, S.S., M.S. Fonseca, and N.B. Stafford. 2006. Seagrass ecology: new contributions from a landscape perspective. In Seagrasses, biology, ecology and conservation, ed. W.D. Larkum, R.J. Orth, and C.M. Duarte, 625-645. The Netherlands: Springer.

Biber, P.D., H.W. Paerl, C.L. Gallegos, and W.J. Kenworthy. 2004. Evaluating indicators of seagrass stress to light. In Estuarine indicators, ed. S.A. Bortone, 193-209. Boca Raton: CRC Press.

Cambridge, M.L., and A.J. McComb. 1984. The loss of seagrasses in Cockburn Sound, Western Australia. I. The time course and magnitude of seagrass decline in relation to industrial development. Aquatic Botany 20: 229-243.

Carpenter, S.R. 2003. Regime shifts in lake ecosystems: pattern and variation. Volume 15 in the excellence in ecology series. Oldendorf/Luhe: Ecology Institute.

Costa, J.E. 1988. Eelgrass in Buzzards Bay: Distribution, production, and historical changes in abundance. EPA 503/4/88-002. pp 204.

Costa, J.E., B.L. Howes, A.E. Giblin, and I. Valiela. 1992. Monitoring nitrogen and indicators of nitrogen loading to support management action in Buzzards Bay. In Ecological indicators vol. 1, ed.
D.H. McKenzie, D.E. Hyatt, and V.J. McDonald, 499-531. Research Triangle Park: Elsevier Applied Science.

Cottam, C. 1934. Eelgrass disappearance has serious effects on waterfowl and industry. US Department of Agriculture Yearbook, Separate 1430.

Cottam, C. 1933. Eelgrass, valuable sea plant, dying of mysterious disease. Science News Letter 24: 73.

Cottam, C., and D.A. Munro. 1954. Eelgrass status and environmental relations. Journal of Wildlife Management 18: 449-460.

Dennison, W.C., R.J. Orth, K.A. Moore, J.C. Stevenson, V. Carter, S. Kollar, P. Bergstrom, and R. Batiuk. 1993. Assessing water quality with submersed aquatic vegetation. Bioscience 43: 86-94.

Dexter, R.W. 1953. Recession of eelgrass at Cape Ann, Massachusetts. Ecology 34: 229-231.

De Jonge, V.N., and D.J. De Jong. 1992. Role of tide, light and fisheries in the decline of Zostera marina L. in the Dutch Wadden Sea. Netherlands Institute for Sea Research, Publication Series No. 20, pp 161-176.

Dobson, J.E., E.A. Bright, R.L. Ferguson, D.W. Field, L.L. Wood, K. D. Haddad, H. Iredale, III, J.R. Jensen, V.V. Klemas, R.J. Orth, and J.P. Thomas. 1995. NOAA Coastal Change Analysis Program (C-CAP): guidance for regional implementation. NOAA Technical Report NMFS 123.

Duarte, C.M., J.W. Fourqurean, D. Krause-Jensen, and B. Olesen. 2006. Dynamics of seagrass stability and change. In Seagrasses, biology, ecology and conservation, ed. W.D. Larkum, R.J. Orth, and C.M. Duarte, 271-294. The Netherlands: Springer.

Duarte, C.M., N. Marba, D. Krause-Jensen, and M. Sanchez-Camacho. 2007. Testing the predictive power of seagrass depth limit models. Estuaries and Coasts 30: 652-656.

Erftemeijer, P.L.A., J.K.L. van Beek, C.A. Ochieng, Z. Jager, and H.J. Los. 2008. Eelgrass seed dispersal via floating generative shoots in the Dutch Wadden Sea: a model approach. Marine Ecology Progress Series 358: 115-124.

Finkbeiner, M., B. Stevenson, and R. Seaman. 2001. Guidance for benthic habitat mapping: an aerial photographic approach. NOAA/CSC/20117-PUB.

Fonseca, M.S., and S.S. Bell. 1998. Influence of physical setting on seagrass landscapes near Beaufort, North Carolina, USA. Marine Ecology Progress Series 171: 109-121.

Fourqurean, J.W., and M.B. Roblee. 1999. Florida Bay: a recent history of ecological changes. Estuaries 22: 345-357.

Frederiksen, M.F., D. Krause-Jensen, M. Holmer, and J.S. Laursen. 2004. Long-term changes in area distribution of eelgrass (Zostera marina) in Danish coastal waters. Aquatic Botany 78: 167-181.

Fox, S.E., E. Stieve, I. Valiela, J. Hauxwell, and J. McClelland. 2008. Macrophyte abundance in Waquoit Bay: effects of land-derived nitrogen loads on seasonal abundance and multi-year biomass patterns. Estuaries and Coasts 31: 532-541.

Green, E.P., and F.T. Short. 2003. World Atlas of seagrasses. Berkeley: University of Calif. Press.

Hauxwell, J., J. Cebrian, C. Furlong, and I. Valiela. 2001. Macroalgal canopies contribute to eelgrass (Zostera marina) decline in temperate estuarine ecosystems. Ecology 82: 1007-1022.

Hauxwell, J., J. Cebrian, and I. Valiela. 2003. Eelgrass Zostera marina loss in temperate estuaries: relationship to land-derived nitrogen loads and effect of light limitation imposed by algae. Marine Ecology Progress Series 247: 59-73.

Holmer, M., and L. Laursen. 2002. Effect of shading of Zostera marina (eelgrass) on sulfur cycling in sediments with contrasting organic matter and sulfide pools. Journal of Experimental Marine Biology and Ecology 270: 25-37.

Kemp, W.M., R. Batiuk, R. Bartlesoni, P. Bergstrom, V. Carter, C.L. Gallegos, W. Hunley, L. Karrh, E. Koch, J.M. Landwehr, K.A. Moore, L. Murray, M. Naylor, N.B. Rybicki, J.C. Stevenson, and D.J. Wilcox. 2004. Habitat requirements for submerged aquatic 
vegetation in the Chesapeake Bay: water quality, light regime, and physical-chemical factors. Estuaries 27: 363-377.

Krause-Jensen, D., S. Sagert, H. Schubert, and C. Bostrom. 2008. Empirical relationships linking distribution and abundance of marine vegetation to eutrophication. Ecological Indicators 8: 515-529.

Leschen, A.S., K.H. Ford, and N. Tay Evans. 2010. Successful eelgrass (Zostera marina) restoration in a formerly eutrophic estuary (Boston Harbor) supports the use of a multifaceceted watershed approach to mitigating eelgrass loss. Estuaries and Coasts. doi:10.1007/s12237-010-9272-7.

Lewis, H.F., and C. Cottam. 1936. Eelgrass and other waterfowl foodspresent status and future prospects. Proceedings of the North American Wildlife Conference 1: 498-501.

McGlathery, K.J. 2001. Macroalgal blooms contribute to the decline of seagrass in nutrient-enriched coastal waters. Journal of Phycology 37: 453-456.

Moore, K.A., and F.T. Short. 2006. Biology of zostera. In Seagrasses, biology, ecology and conservation, ed. W.D. Larkum, R.J. Orth, and C.M. Duarte, 361-386. The Netherlands: Springer.

Odale, R.N. 1992. Cape Cod and the Islands: the geology of Cape Cod. East Orleans: Parnassus Imprints.

Olsen, J.L., S.T. Wytze, J.A. Coyer, T.H. Reusch, M. Billingham, C. Bostrom, E. Calvert, H. Christie, S. Granger, R. La Lumiere, N. Milchakova, M.P. Oudot-Le Secq, G. Procaccini, B. Sanjabi, E. Serrao, J. Veldsink, S. Widdicombe, and S. Wyllie-Echeverria. 2004. North Atlantic phylogeography and large-scale population differentiation of the seagrass Zostera marina L. Molecular Ecology 13: 1923-1941.

Orth, R.J., and K. Moore. 1983. Chesapeake Bay: an unprecedented decline in submerged aquatic vegetation. Science 222: 51-52.

Orth, R.J., M.L. Luckenback, S.R. Marion, K.A. Moore, and D.J. Wilcox. 2006a. Seagrass recovery in the Delmarva Coastal Bays, USA. Aquatic Botany 84: 26-36.

Orth, R.J., M.C. Harwell, and G.J. Inglis. 2006b. Ecology of seagrass seeds and dispersal strategies. In Seagrasses, biology, ecology and conservation, ed. W.D. Larkum, R.J. Orth, and C.M. Duarte, 111-133. The Netherlands: Springer.

Orth, R.J., T.J.B. Carruthers, W.C. Dennison, C.M. Duarte, J.W. Fourqurean, K.L. Heck Jr., A.R. Hughes, G.A. Hendrick, W.J. Kenworthy, S. Olyarnik, F.T. Short, M. Waycott, and S.L. Williams. 2006c. A global crisis for seagrass ecosystems. Bioscience 56: 987-996.

Orth, R.J., M.R. Williams, S.R. Marion, D.J. Wilcox, T.J.B. Carruthers, K.A. Moore, W.M. Kemp, W.C. Dennison, N. Rybicki, P. Bergstrom, and R.A. Batiuk. 2010. Long-term trends in submersed aquatic vegetation (SAV) in Chesapeake Bay, USA, related to water quality. Estuaries and Coasts 33: 1144-1163.

Rasmussen, E. 1977. The wasting disease of eelgrass (Zostera marina) and its effects on environmental factors and fauna. In Seagrass ecosystems, ed. C.P. McRoy and C. Helfferich, 1-51. New York: Marcel Dekker.

Scheffer, M., and S.R. Carpenter. 2003. Catastrophic regime shifts in ecosystems: linking theory to observation. Trends in Ecology and Evolution 12: 648-656.

Short, F.R., and S. Wyllie Echeverria. 1996. Natural and human induced disturbance of seagrasses. Environmental Conservation 23: 17-27.

Short, F.T., B.W. Ibelings, and C. den Hartog. 1988. Comparison of a current eelgrass disease to the wasting disease in the 1930s. Aquatic Botany 30: 295-304.

Short, F.T., and D.M. Burdick. 1996. Quantifying eelgrass habitat loss in relation to housing development and nitrogen loading in Waquoit Bay, MA. Estuaries 19: 730-739.

Steward, J.S., and W.C. Green. 2007. Setting load limits for nutrients and suspended solids based upon seagrass depth-limit targets. Estuaries and Coasts 30: 657-670.

Thayer, Gordon W., W. Judson Kenworthy, and Mark S. Fonseca. 1984. The ecology of eelgrass meadows of the Atlantic coast: a community profile. US Fish and Wildlife Service. FWS/OBS-84/ 02. pp 147.

Tomasko, D.A., D.L. Bristol, and J.A. Ott. 2001. Assessment of present and future nitrogen loads, water quality, and seagrass (Thalassia testudinum) depth distribution in Lemon Bay Florida. Estuaries 24: 926-938.

Valiela, I., and J.E. Costa. 1988. Eutrophication of Buttermilk Bay: a Cape Cod coastal embayment: concentrations of nutrients and watershed nutrient budgets. Environmental Management 12: $539-553$.

Valiela, I., K. Foreman, M. LaMontague, D. Hersh, J. Costa, P. Peckol, B. DeMeo-Anderson, C. D’Avanzo, M. Babione, C.H. Sham, J. Brawley, and K. Lajth. 1992. Coupling of watersheds and coastal waters: sources and consequences of nutrient enrichment in Waquoit Bay, Massachusetts. Estuaries 15: 443457.

Vaudrey, J.M.P., J.N. Kremer, B.F. Branco, and F.T. Short. 2010. Eelgrass recovery after nutrient enrichment reversal. Aquatic Botany. doi:10.1016/j.aquabot.2010.08.005.

Walker, D.I., G.A. Kendrick, and A.J. McComb. 2006. Decline and recovery of seagrass ecosystems - the dynamics of change. In Seagrasses, biology, ecology and conservation, ed. W.D. Larkum, R.J. Orth, and C.M. Duarte, 551-565. The Netherlands: Springer.

Waycott, M., C.M. Duarte, T.J.B. Carruthers, R.G. Orth, W.C. Dennison, S. Olyarnik, A. Calladine, J.W. Fourqurean, K.A. Heck Jr., A.R. Hughes, G.A. Kendrick, W.J. Kenworthy, F.T. Short, and S.L. Williams. 2009. Accelerating loss of seagrasses across the globe threatens coastal ecosystems. Proceedings of the National Academy of Sciences 106: 12377-12381.

Wyllie-Echeverria, S., P. Arzel, and P.A. Cox. 2000. Seagrass conservation: lessons from ethnobotany. Pacific Conservation Biolgy 5: 329-335. 